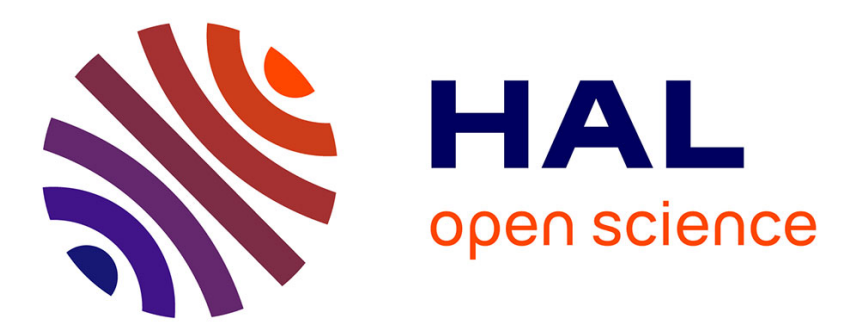

\title{
Politics is sublime
}

Mustafa Dikec

\section{To cite this version:}

Mustafa Dikec. Politics is sublime. Environment and Planning D: Society and Space, 2012, 10.1068/d12610 . hal-01274402

\section{HAL Id: hal-01274402 \\ https://hal-enpc.archives-ouvertes.fr/hal-01274402}

Submitted on 15 Feb 2016

HAL is a multi-disciplinary open access archive for the deposit and dissemination of scientific research documents, whether they are published or not. The documents may come from teaching and research institutions in France or abroad, or from public or private research centers.
L'archive ouverte pluridisciplinaire HAL, est destinée au dépôt et à la diffusion de documents scientifiques de niveau recherche, publiés ou non, émanant des établissements d'enseignement et de recherche français ou étrangers, des laboratoires publics ou privés. 


\title{
Politics is sublime
}

\section{Mustafa Dikeç}

Department of Geography, Royal Holloway, University of London, Egham, Surrey TW20 0EX, England; e-mail: m.dikec@rhul.ac.uk

Received 14 July 2010; in revised form 3 June 2011

\begin{abstract}
This paper examines the political aesthetic of Hannah Arendt and Jacques Rancière who in their own ways, found resources in an innovative reading of Kant's Critique of Judgment . The paper explores the Kantian legacy in the political understanding of these two thinkers. It then focuses on Rancière's notion of dissensus and argues that his politics shares the aesthetic features associated with the Kantian sublime.
\end{abstract}

Keywords: politics, aesthetics, sublime, common sense, dissensus, Arendt, Kant, Rancière

\section{Castella, the factory owner}

Castella has a big moustache, and he tells vulgar jokes. He does not like reading, he does not like the theatre. He spends his days at a factory, which belongs to him, and his evenings at the theatre, to which he seemingly does not belong. His unrefined ways, lack of education, and lack of artistic culture make him an object of ridicule when he joins the artists for dinner after the spectacle, with the hope of gaining the sympathy of the lead actress, Clara, with whom he has fallen madly in love.

But they seem worlds apart. Castella's efforts seem merely to consolidate his position as a joking matter in this artistic milieu. In yet another effort to be close to Clara, Castella attends an exhibition by one of her painter friends and buys a painting. But how could this moustachioed industrialist have a taste for painting not induced by some other motivation? The painter's boyfriend believes that Castella felt obliged to buy it after having unwittingly insulted him and his boyfriend - the painter - with a pejorative remark on gays. Clara thinks Castella is buying art to impress her. But Castella goes even further: he commissions the painter to paint a mural on the façade of his factory, which happens to be a paint factory.

Although the painter's boyfriend believes that Castella has commissioned his boyfriend because he appreciates his art, Clara thinks they are taking advantage of his feelings towards her. "I know Castella", she says, "he doesn't appreciate it. He doesn't know a thing." But when she visits the factory to put an end to this 'exploitation', as she sees it, Castella surprises her by telling her that he actually likes the paintings, and that is why he is buying them. "You didn't think for a minute it could be because I liked them? Don't worry", he assures Clara, "it's because I like them."

Clara is speechless; even this uneducated, vulgar factory owner - who doesn't know, as she said, a thing - has taste. He is not, as she wrongly believed, trying to satisfy 'the taste of others' - the film's title ${ }^{(1)}$ - but his own. There is something egalitarian here: Castella is capable of making judgments of taste, just like her, her painter friend, and all the others. 
What political lessons can be drawn from this story? There is one obvious route to take, following Bourdieu, and to read this as a critique of taste. We would then see poor Castella as humiliated and oppressed because of his lack of taste, which is the result of his lack of education, cultural capital, and so on. This would then imply a politics that would denounce all grantors and grounds for privilege (elite schools, social, cultural, and institutional structures), and in this sense it would be an egalitarian politics with equality as its objective. This is a fine politics, but it denies all capacity to Castella, who can play only the role of 'poor Castella' in this scenario-indeed, he has to remain only that for the critique to have any legitimacy at all. If there is any hope for emancipation for Castella, it will come from the critic's denunciation of such markers of privilege and distinction.

Can we make Castella play a different role, a part where he emancipates himself by demonstrating a capacity that is denied to him? The aim of this paper is to show on what basis we could answer this question in the affirmative, and what this implies for thinking politics. Through an exploration of Jacques Rancière's political aestheticwhere equality is taken as a given rather than as abjective to be attained-I consider an aesthetic mode of political thinking that is not constructed around epistemological justification (knowledge/truth claims) or means - end calculation. This implies a political relation to the world that is not one of knowing, but one of aesthetics, and I am interested in the political implications of such an aesthetic orientation. ${ }^{(2)}$

There is, however, a risk involved in such an endeavour, as illustrated by Martin Jay's (1992) review of what 'aesthetic' and 'aestheticised politics' may mean. He identifies three strands. The first uses the term aesthetic to define an autonomous and disinterested realm of art from which nonaesthetic criteria are deliberately excluded - art for art's sake, in short. Politics aestheticised in this sense puts aesthetic worth and radical disinterestedness over human life and interests, an extreme example of which would be Mussolini's son-in-law's admiration of the beauty of the bombs dropped on Ethiopians by him comparing them to flowers bursting into bloom. ${ }^{(3)}$ Partly related to this, a second use of the term aesthetic in association with politics reflects an artistic and elitist will to shape matter. Jay's example here is the fascist adoption of this idea, as illustrated by Mussolini's comparison of the masses to wax in his hands. Whereas these two uses illustrate the dominance of art over life and artistic will over 'masses', Jay identifies a third use, where aesthetics is associated with "the seductive power of images". This form of aestheticised politics indicates "the victory of the spectacle over the public sphere", where any potential for rational deliberation in public space is overwhelmed by images in a spellbinding yet illusionary spectacle (1992, page 45).

The connotations of aestheticised politics that come out of Jay's review are not gratifying: "irrationality, illusion, fantasy, myth, sensual seduction, the imposition of will, and inhumane indifference to ethical, religious, or cognitive considerations" (page 45). As Jay observes, Benjamin's association of fascism with the introduction of aesthetics into politics has led to the establishment of a firm link between "the aestheticization of politics" and fascism. But the link between aesthetics and politics is not necessarily evil. Jay notes that there are other implications of aestheticising politics rather than "hastily turning all aesthetic politics into a prolegomenon to tyranny" (1992, page 51). His examples are through Hannah Arendt and Jean François Lyotard, both

(2) It is not my aim to cover the literature on various aesthetic theories of politics. For a sample, see Kennan Ferguson (2007, page 133, note 1).

(3) Jay (1992, page 44) notes Walter Benjamin's “bitter observation that mankind's 'self-alienation has reached such a degree that it can experience its own destruction as an aesthetic pleasure of the first order' ('Work of Art' 244) [which] vividly expresses the disgust aroused by this callous apotheosis of art over life". 
of whom were inspired by Kant's theory of aesthetic judgment in their understanding of politics/ethics while eschewing the sort of aestheticised politics that has been associated with fascism.

This paper focuses on Rancière as a thinker of politics and aesthetics, or, better yet, politics as aesthetics. My account is structured around what I call the three Kantian legacies' in his politics. Rancière, I argue, establishes an original relationship between aesthetics, equality, and freedom based on an unorthodox interpretation of Kant's first and third critiques (Critique of Pure Reason and Critique of Judgment). ${ }^{(4)}$ To highlight the peculiarity of Rancière's appropriation of Kant, I supplement my analysis of his work with a section on Arendt, which allows me to tease out their differences and clarify what I see as their aestheticism. Both Arendt and Rancière share a debt to Kant for their political aesthetic, the source of which is found in his writings on taste and aesthetic judgment in the third Critique. While Arendt found the third Critique politically appealing for its account of sociability and communicability, Rancière was more inspired by its postulate of decentred subject and its implications for dissensus.

As we will see, Arendt develops a political aesthetic that emphasises an appeal to common sense (its Kantian version) for the creation of common worlds in a context of plurality. Rancière's politics, on the other hand, implies a disruption of 'common sense, of what is commonly made available to the senses and made to make sense. The emphasis is not on judging as such - as it is with Arendt-but on what making a judgment implies. We are less interested in Castella's judgment (Does he like the painting? Does he not?) than in his verification of a shared capacity-even he, who does not 'know a thing', is capable of making aesthetic judgments.

The Kantian influence is less direct in Rancière than it is in Arendt. Rancière mobilises an understanding of aesthetics to evoke forms of perceiving the world and modes of relating to it. Politics implies a disruption of established, habitual, inherited, or 'common sense' forms and modes of perceiving and relating to the world. This is what leads to my association of his politics with the aesthetic features of the Kantian sublime, as something that defeats our senses, disrupts our ordinary ways of perceiving and making sense of the world. Here my argument is informed by Deleuze's account of the fragility of the Kantian synthesis in the face of the sublime. ${ }^{(5)}$ What the sublime disrupts is our aesthetic relation to the world, although such a disruption does not necessarily imply 'good' politics. Totalitarian regimes, fascist governments, military coups also radically disrupt our ways of perceiving and relating to the world. In evoking the image of the sublime, therefore, I do not advocate an unconditional espousal of disruptive and transformative politics for the sake of disruption and transformation. We will see the limitations of such a position below, in Cascardi's attempt to develop a sublime aestheticisation of Arendt's politics.

\section{Kant, the sociable}

Arendt saw Kant's third Critique as his 'unwritten' political philosophy. Kant's understanding of aesthetic judgment as free from rules and standards resonated strongly with her understanding of politics as dissociated from anything that is likely to compel assent. Yet, it was the idea of a 'potential agreement with others' that she found politically relevant in Kant's aesthetic theory, for it implied the creation of common worlds in a context of plurality.

(4) The edition I am using translates the title of the third Critique as Critique of the Power of Judgment. In the text, however, I will refer to it as Critique of Judgment (or CJ), as it is more commonly known.

(5) This is not, however, meant to imply that Rancière and Deleuze are engaged in the same project. 
Plurality is the basis of Arendt's aestheticism; it is the very condition of reality in an appearing world. "Plurality", she writes, "is the law of the earth" (1978, page 19). With this presupposition of plurality assuring the existence of 'what is', Arendt develops her political aesthetic first in terms of action, then, later in life, in terms of reflection. In her earlier writings, she focuses on the relationship between judgment and action, where judgment is seen to guide political actors. In her later writings, however, Arendt explores judgment from the viewpoint of the spectator who is reflecting on the meaning and significance of past events, and argues that "[t]he spectator, not the actor, holds the clue to the meaning of human affairs" (1978, page 96).

This shift "from the judgment of the engaged political actor... to that of the detached spectator" (Villa, 2000, page 16) gave rise to a debate about whether Arendt had two different 'models' of judgment (Beiner, 1992; Passerin d'Entrèves, 2000). ${ }^{(6)}$ In both 'models', however, Arendt maintains the hallmark of her political aesthetic-plurality. Whether from the perspective of the actor or of the spectator, her understanding of judgment impliesrequires even - plurality, being involved with others. In this sense, Arendt's actor/spectator split is perhaps best understood as part of her aestheticism, rather than as a valorisation of reflection over action. ${ }^{(7)}$ As Curtis (1997) argues, in Arendt's work we find an 'ontology of display' that requires a mutual sensuous provocation between actors and spectators through which 'what is' comes into being and common worlds are created. Her political aesthetic implies "worldly involvement with others" (McClure, 1997, page 74). This may seem more evident in the case of acting with and in the presence of others, but even judging, as she saw it, is made "to get into community with others" (1992, page 40; Kant's formulation in Arendt's translation). But how is that possible when one is engaged in such a seemingly subjective, even isolated, activity as judging? This is where Kant comes to the rescue.

For Kant, judgments of taste do not compel agreement in the way truth claims do. But they are not about merely subjective preferences either; in judgments of taste (or, aesthetic judgments), there is a claim on the agreement of others. They "share with political opinions that they are persuasive; the judging person - as Kant says quite beautifully — can only 'woo the consent of everyone else' in the hope of coming to an agreement with him eventually" (Arendt, 2006, page 219). ${ }^{(8)}$ What is at stake here is not knowledge or truth,

(6) This, in turn, gave rise to another debate about the different philosophical sources of these 'models'; Aristotle, for the actor-oriented model, and Kant, for the spectator-oriented one. See Passerin d'Entrèves (2000); also see Ferrara (2008) for an argument that these are not necessarily mutually inconsistent.

(7) For Hutchings (1996, page 188), this shift in focus shadowed "Arendt's heroic, agonistic conception of political action ... by the authoritative, though inscrutable, verdict of the onlooker". Villa (2000) argues, however, that it is not

"plausible to suggest that Arendt came to abandon her stress on what Jerome Kohn calls 'the priority of the political' in favour of a secular form of theodicy. It is better, I think, to view this phase of Arendt's work as an attempt to think through the tension between the life of the citizen and the life of the mind. In many respects, this tension occupied Arendt throughout her intellectual career" (page 17).

I do not think, therefore, that Arendt somehow 'sacrificed' political action in favour of a detached spectatorship; the life of the political actor and the life of the mind are not mutually exclusive. As Hutchings notes, her shift in focus from action to judgment was facilitated by her coverage of the Eichmann trial, and we must remember that Arendt is "a thinker for whom thoughtlessness accompanied the greatest of modern political disasters" (McClure, 1997, page 62).

${ }^{(8)}$ This is Arendt's translation from $\$ 19$ of Kant's third Critique. The section reads (Guyer and Matthews translation):

"The judgment of taste ascribes assent to everyone, and whoever declares something to be beautiful wishes that everyone should approve of the object in question and similarly declare it to be beautiful. The should in aesthetic judgments of taste is thus pronounced only conditionally even given all the data that are required for the judging. One solicits assent from everyone else because one has a ground for it that is common to all." 
"but rather judgment and decision, the judicious exchange of opinion about the sphere of public life and the common world, and the decision what manner of action is to be taken in it, as well as to how it is to look henceforth, what kind of things are to appear in it" (pages 219-220). What makes laying a claim on the agreement of others is something shared by all humans: sensus communis. Common sense (sensus communis) is not an empirical problem for Kant; it is a presupposition that makes aesthetic judgments universally communicable:

"By 'sensus communis'... must be understood the idea of a communal sense, ie, a faculty for judging that in its reflection takes account (a priori) of everyone else's way of representing in thought, in order as it were to hold its judgement up to human reason as a whole and thereby avoid the illusion which, from subjective private conditions that could easily be held to be objective, would have detrimental influence on the judgement" ( $C J, \S 40$; see also $\$ 20$ and $\S 21)$.

Private interests and motivations are left aside when judging aesthetically, and it is here that Arendt sees the political import of Kant's notion: sensus communis 'liberates' our judgments from the confines of our own subjectivity and makes them 'communicable'. Judgments, Kant insisted, must "be able to be universally communicated" $(C J, \S 21)$. But why is this politically pertinent for Arendt? This brings us back to the basis of Arendt's aestheticism - plurality - which she saw as "the condition of all political life" (1998, page 7, original emphasis):

"The power of judgement rests on a potential agreement with others, and the thinking process which is active in judging something is not, like the thought process of pure reasoning, a dialogue between me and myself, but finds itself always and primarily, even if I am quite alone in making up my mind, in an anticipated communication with others with whom I know I must finally come to some agreement .... [Judgement] needs the presence of others 'in whose place' it must think, whose perspectives it must take into consideration.... As logic, to be sound, depends on the presence of the self, so judgement, to be valid, depends on the presence of others. Hence judgement is endowed with a certain specific validity but is never universally valid" (Arendt, 2006, page 217).

This is what makes judgment "a specifically political ability" for Arendt, because it implies a shift from the self towards others and allows one "to see things not only from one's own point of view but in the perspective of all those who happen to be present.... Common sense... discloses to us the nature of the world insofar as it is a common world ... . Judging is one, if not the most, important activity in which this sharingthe-world-with-others comes to pass" (Arendt, 2006, pages 217-218, emphasis added). ${ }^{(9)}$

The Kantian common sense, as we saw, is not a standard or rule to be applied; not something, in short, that governs judgments. Yet we appeal to it to make our seemingly subjective aesthetic judgments universally communicable. Kant emphasises that it is a sense, or, "[m]ore specifically, it is a sense (or feeling) for what is universally communicable, which can also be assumed to be universally shared. Otherwise expressed, it is a shared capacity to feel what may be universally shareable" (Allison, 2001, page 149). ${ }^{(10)}$ Kant presumes that all human beings share such a sense or capacity, because otherwise

(9) "In point of fact", writes Arendt elsewhere, "the real political faculty in Kant's philosophy is not lawgiving reason, but judgement, which in an enlarged mentality has the power to override its 'subjective private conditions'” (2005, page 169).

(10) This is what Ferrara calls "Kant's strategy of 'naturalizing' sensus communis". Kant "tries to show that sensus communis, understood as a shared feeling, is presupposed by the very idea of the communicability of pleasure - a communicability that in turn can be seen as connected with the structure and interrelation of the imagination and the understanding, arguably shared by all human beings" (2008, pages 27 and 28). 
our judgments "would have no correspondence with the object: they would all be a merely subjective play of the powers of representation, just as scepticism insists" ( $C J$, $\S 21)$. Thus, the idea of universal communicability based on common sense as shared sense or capacity is what allows our judgments to go beyond a mere subjective play of our mental faculties (Ferrara, 2008).

In Arendtian terms, if we did not have such a presupposition, we would lose all possibility for the creation of common worlds, which is central to her political aesthetic. There is something 'associative' about Kant's sensus communis, something that allows relating to one another based on this assumption of universal communicability. This is partly what is so appealing to Arendt, for the creation of common worlds (through acting or judging) implies relatedness to others without necessarily postulating unity, convergence, or consensus. The Kantian sensus communis indicates "an extra sense-like an extra mental capability... that fits us into a community." It is "what judgement appeals to in everyone, and it is this possible appeal that gives judgements their special validity" (Arendt, 1992, pages 70 and 72). We can at best 'woo' or 'court' the agreement of others, but our judgments do not compel assent, as truth claims do. "[O]ne can never compel anyone to agree with one's judgments - 'This is beautiful' or 'This is wrong'...; one can only 'woo' or 'court' the agreement of everyone else. And in this persuasive activity one actually appeals to the 'community sense'. In other words, when one judges, one judges as a member of a community" (Arendt, 1992, page 72).

This raises a question about whether common sense is empirical (a product of actual communities) or transcendental (a given condition of judgment), as Kant seems to suggest. Here Beiner and Nedelsky (2001) spot a difference between Kant and Arendt, and argue that, while both agree that common sense is what makes judgments possible and universally communicable, its source is different for them. For Kant, common sense is grounded in our universally shared cognitive faculties. Arendt limits it to the community of those who judge. So while the common sense for Kant is 'natural', for Arendt it seems more of a historical or empirical problem based in actual community rather than in a shared capacity (see also Beiner, 1992). This tension is not entirely resolved by Arendt (Hutchings, 1996), though given her broader political project, communitarian readings of her work do not seem entirely convincing. As Villa argues, "it is precisely the distance, disinterestedness, and alienation of Kant's aesthetics that attracts Arendt in the first place". What is significant in Kant's idea of aesthetic judgment is that the individual is not subsumed under community, and in following him, what Arendt has in mind is a notion of 'worldliness' that is "not reducible to the "situatedness' promoted by the communitarians" (Villa, 2001, pages 301 and 302).

As we will see below, Rancière also deals with a similar kind of tension when he posits the disruption of common ways of perceiving the world-distribution of the sensible - as defining moment of politics, which also relies on a common capacity. This is inspired, I will argue, by Kant's theory of aesthetic judgment, but in Rancière takes the form of an axiomatic equality - equality of anyone with anyone - that only in its verification, only in its actualisation in space and time, alters forms and modes of perceiving and relating to the world. This implies a disruption of habitual ways of making sense of the world, and this is why I associate Rancière's politics with the aesthetic features of the Kantian sublime.

Can a similar association be made with Arendt's politics as well? For Cascardi (1997, page 111), Arendt's account of judgment "recoils from the sublime", thus neglecting those instances where we are overwhelmed by the presentation of the unpresentable. Arendt's politics is thus geared towards "normativity through representability" (page 126), and its 
transformative potential is dramatically weakened. Cascardi argues that by neglecting the sublime, Arendt does not take into account that which exceeds representation, and thus fails to propose a "politics of radical transformation".

However, as Fraser (1997, page 167) observes, this is "a highly idiosyncratic reading of Arendt", whose politics is usually associated with a performative and agonistic public space. And this seemingly unconditional privileging of the sublime by Cascardi leads to two difficulties. First, it polarises communicative politics and transformative politics to such an extent that we either have one or the other. Cascardi seems to assume that "consensus is always bad and its disruption is always good" (Fraser, 1997, page 168), valorising disruption and transformation for their own sake. As Fraser puts it, it is "plainly false" to assume that disruption is always good: "It is one thing to disrupt a consensus that sees nothing unacceptable in, say, marital rape, and another to disrupt a consensus to the contrary. In the first case, the consensus is unjust and its disruption is a step toward justice; in the second, just the opposite is true" (1997, pages $168-169$ ).

Furthermore, this unconditional valorisation of disruption is accompanied by an unconditional valorisation of unrepresentability. "To be sure", Fraser (1997, page 169, original emphasis) argues, "radical democrats ought to be interested in what (and who) can't be represented within some given, historically and spatially located discursive regime. An idea, in contrast, that resists all possible representation has an air of surplus paradox suited better to religion than to politics." As we will see, this idea of sublime unrepresentability is also what Lyotard finds appealing in Kant's theory of aesthetic judgment much to the contempt of Rancière.

Jay (1997) shares Fraser's doubts about the emancipatory potential of an understanding of politics around an aesthetics of sublime unrepresentability. "To the extent that the sublime makes us silent in the face of what we cannot say or represent", he writes, "it comes uncomfortably close to the violence that Arendt wants to distinguish from the political" (page 342). While Jay is extremely troubled by Cascardi's argument for a sublime aestheticisation of politics, he is not too comfortable with Arendt's aestheticisation of it either. The "link between the sublime aestheticization of politics - indeed, any purely aesthetic reading of politics - and violence" (page 342), he insists, must be considered seriously as they recall memories of totalitarian and fascist politics.

Kateb also expresses concern about what he sees as Arendt's attempt to "transform ... political phenomena into aesthetic phenomena". He argues that she subordinates practicality and morality to aesthetics, and tries to free politics from abstract, universal truths. To put it differently, Arendt's political actors-properly understood-are "nonmoral, noninstrumental, and nondogmatic" (2001, page 128). Although the aesthetic aspect of Arendt's politics raises concern-for its disjunction from morality and rationality, and its affinity with fascist ideology - it is also what makes her politics creative and disruptive. This is what Kateb calls "Arendt's political aestheticism", and he illustrates this through the example of artworks:

"Artworks are expressions of a distinctive human capacity: to do something new, creative, unexpected, eruptive, interruptive of routinized perception and response. Although rules and discipline enter into the making of art, art is far more than rules or discipline. Art is the freedom of humanity" (2001, page 124).

Kateb's illustration brings us close to Rancière, whose understanding of politics is distinctly aesthetic. Inspired by Kant's aesthetic in many ways, Rancière proposes a notion of politics based on dissensus, which shares, as I will suggest, the aesthetic features associated with the Kantian sublime in its disruption of 'routinized perception and response'. However, by putting equality at the heart of his politics, by focusing 
on instances where equality is 'wronged' by established aesthetic regimes, he avoids valorising disruption for its own sake.

\section{Kant, the radical}

There is, for Rancière, "an 'aesthetics' at the core of politics that has nothing to do with Benjamin's discussion of the 'aestheticization of politics' specific to the 'age of masses'. This aesthetics should not be understood as the perverse commandeering of politics by a will to art, by a consideration of the people qua work of art" (2004a, page 13). Indeed, he even argues that "[ $\mathrm{t}]$ here never has been any 'aestheticization' of politics in the modern age because politics is aesthetic in principle" (1999, page 58). Politics, for Rancière, is a polemical-not consensual-redistribution of identities, spaces and times, objects and subjects, and it is in this sense that he calls politics an "aesthetic activity" (2009a, page 32). This aspect of Rancière's thinking has its sources in his earlier, more 'historical' work, notably The Nights of Labor, The Philosopher and His Poor, and The Ignorant Schoolmaster. As he put it himself (2005), the aesthetic dimension of politics has been his basic concern throughout his research (except, perhaps, during his brief Althusserian moment as a student). Before considering how he establishes a relation between aesthetics and politics, however, it is important first to get a sense of what 'aesthetics' refers to in his work.

When considering the aesthetic dimension of politics, Rancière admittedly uses 'aesthetic' in a sense "close to the Kantian idea of 'a priori forms of sensibility': it is not a matter of art and taste: it is, first of all, a matter of time and space" (2005, page 13). Although not conceptually organised around aesthetics, The Nights of Labor (1989) was a prime example of this, where Rancière provided an account of how the workers' time and space were organised. The division they had to abide by - work and rest-prevented them from doing anything other than what this partitioning imposed. At night, the worker had to sleep rather than to think, write, or discuss so that she or he would be ready for work the next morning. Emancipation implied undoing this order. This is a common thread in Rancière's work: that systems of domination impose or consolidate spatial and temporal orders, and politics is about disrupting them.

This aesthetic dimension is the first Kantian legacy in Rancière's politics. But this is the aesthetic of Kant's first Critique, the Critique of Pure Reason, rather than the aesthetics of his third Critique (which, we will see, provides the ground for the other two Kantian legacies, axiomatic equality ${ }^{(11)}$ and dissensus). Kant's transcendental philosophy was concerned with the a priori conditions that make our experience of the world possible, and the focus of his firs Critique was on mental abilities of cognition as part of our experience of the world. The part where he dealt with sensibility in the first Critique was the 'Transcendental Aesthetic', where he famously defined space and time as a priori forms of intuition or sensibility. As a priori forms, space and time make objects possible and organise the multitude of sensations we receive into a whole, and thus give form to our experience of the world. We encounter particular objects, and become aware of them as spatially (and temporally) ordered - as

(11) Rancière may also have been inspired by Joseph Jacotot, a French schoolteacher he encountered during his research in the archives. Exiled in the Netherlands, Jacotot caused quite a stir in 19thcentury pedagogical debates when he claimed that all people had equal intelligence. His aim, however, was not proving empirically that all intelligence was equal; it was to see "what can be done under that supposition" (Rancière, 1991, page 46). Even though Rancière had already started building his political thought before this encounter, he notes that what appealed to him in Jacotot was "the radical manner in which [he] formulated the egalitarian idea" (2004b, pages 222-223). 
exhibiting relations of simultaneity and succession — and as having a form - possessing spatial features such as shape and extension. According to Kant, this spatial (or temporal) system of relations is a priori and has its source in our minds. That it is a priori means, however, that it is already given to us, built in our minds, that it does not rely on experience, but merely gives form to our awareness of things in space (and time).

Rancière does not follow Kant to the letter; his is an interpretation rather than an application of the Kantian idea of a priori forms of sensibility. He specifies that he "does not deal with time and space as forms of presentation of the objects of our knowledge." For him, they are "forms of configuration of our 'place' in society, forms of distribution of the common and the private, and of assignation to everybody of his or her own part" (2005, page 13). ${ }^{(12)}$ If Kant dealt with aesthetics as a priori forms that order what presents itself to sense experience, Rancière deals with it as a "partition of the sensible" (le partage du sensible), evoking at once the first Critique's concern with the form of what is presented to the senses, and the third Critique's concern with aesthetics as a form of relating to the world. The word 'partage' is oxymoronic as it means both 'partition' and 'sharing'. Rancière uses it to refer to both what is "put in common" (mis en commun) and shared in the community - à partager - and also what is separated and excluded-partagé - such as the separation of the visible and invisible, audible and inaudible, speech and noise. There is, however, another meaning of the word: as used in the phrase 'en partage', it refers to an inheritance, an endowment (usually positive, such as talent). So another connotation of 'le partage $d u$ sensible' would be to be given certain ways of perceiving and making sense of things - habitual, routinised, or normalised ways of perceiving and making sense of things, the disruption of which is the sublime aspect of Rancière's politics.

Rancière, therefore, both alters and expands the notion of a priori forms, which are no longer in the mind-where Kant had them-but in particular historical and geographical contexts as products of processes, conflicts, and tensions. The partition of the sensible is a contingent distribution of forms that structure common-though not consensual-experience, marked by tension and conflict. "A partition of the sensible", writes Rancière', "is always a state of forces [état des forces]" (2009b, page 158). ${ }^{(13)}$

\section{Gauny, the floor-layer}

Gabriel Gauny, one of Rancière's 19th-century workers, is a central figure in the first part of The Nights of Labor. He is a floor-layer by day, an intellectual by night, refusing to abide by the divide established between work and rest. There is a particular passage in Gauny's journals that Rancière cites, where Gauny is reflecting on himself while working at the house of a bourgeois family:

"Believing himself at home, he loves the arrangement of a room so long as he has not finished laying the floor. If the window opens out on a garden or commands a view of a picturesque horizon, he stops his arms a moment and glides in imagination toward the spacious view to enjoy it better than the possessors of the neighbouring residences."

(12) Note that he is not talking about space and time as such, although what is implied is the way certain orders gets spatialised and/or temporalised.

(13) Rancière acknowledges Foucault's influence as well: "The idea of the partition of the sensible is no doubt my own way of translating and appropriating for my own account the genealogical thought of Foucault - his way of systemizing how things can be visible, utterable, and capable of being thought" (2000, page 13). It may be helpful to recall that Rancière uses another term to refer to such distributions: 'the police' - a hierarchical order that consolidates partitions of the sensible [see, for example, chapter 2 of Rancière (1999); see also Dikeç (2005) on the spatiality of the police]. 
For Rancière, this reads like "a personal paraphrase of the Critique of Judgment". Gauny ignores the fact that the house does not belong to him, but acts "as if what was being enjoyed by the gaze also belonged to him" (2006, pages $4-5$, original emphasis). There is a disjunction between what his occupation tells his arms to do, and his capacity that allows his gaze to follow and appreciate a beautiful scene. Although The Nights of Labor does not relate this to Kant, Rancière makes this connection explicit in his later writings, stating that Gauny, in a sense, confirmed Kant's analytic of the beautiful: "in order to appreciate the form of a palace, one needs to drop the question of knowing how the sweat of the people serves to construct the privileges of the rich." This does not, of course, mean that one should not care about such things; the moral of the story lies elsewhere: "it is the possibility of this 'disinterested' gaze that emancipates the worker" (Rancière, 2009b, page 169). But how does Rancière move from Gauny the floor-layer to the palace, and, from there, to emancipation?

The answer is Kant's peculiar conception of aesthetic judgment in the third Critique. For Kant, aesthetic judgments (or judgments of taste) are reflective judgments. These differ from determinative judgments because they proceed without a concept. In the Critique of Pure Reason, Kant defines judgment as "the faculty of subsuming under rules, ie, of determining whether something stands under a given rule... or not" (A133/B172). Without this faculty, without, that is, concepts with which to classify particulars, we cannot have knowledge. But not all judgments are the same, and Kant provides a distinction in Critique of Judgment:

"The power of judgement in general is the faculty for thinking of the particular as contained under the universal. If the universal (the rule, the principle, the law) is given, then the power of judgement, which subsumes the particular under it ... is determining. If, however, only the particular is given, for which the universal is to be found, then the power of judgement is merely reflecting" ( $C J$, Introduction, section IV, original emphasis). ${ }^{(14)}$

This means that aesthetic judgments, as reflective (or reflecting) judgments, do not contribute to knowledge because they are made in the absence of concepts. The peculiar aspect of Kant's theory of aesthetic judgment is that we all, by our very nature, have the ability to judge things as beautiful or sublime. Rather than establishing rules for distinguishing the beautiful, it establishes aesthetic judgment as an equally shared capacity in all humans, and we have seen how this appealed to Arendt for its implications of 'getting into community with others'.

Judgments of taste are not aesthetic because they are about appreciating 'beautiful' objects. Indeed, an aesthetic judgment does not even refer to any descriptive qualities of the object; all it does is to 'affirm' its beauty. As Panagia (2006, page 70, original emphasis) puts it, in an aesthetic judgment, "we affirm rather than declare an object beautiful and we presume that everyone understands such an affirmation". Such judgments are aesthetic because they are about being affected. In an aesthetic judgment, our relation to the world (and to each other) is one of sensibility rather than one of knowing. We neither identify nor determine anything in the object presented to our senses, but judge it solely in its particularity. An aesthetic judgment is subjective not because it is about individual preferences, but because it is not based on a concept about the object, and, in this sense, it is not dependent on the object. All aesthetic judgments, Kant holds, are singular judgments where we judge the object or event in its singularity.

(14) To avoid a possible confusion, note that Kant wrote two introductions to the $C J$. The first was not published, and in scholarly writing it is referred to as the 'First Introduction'. This is included in the Cambridge edition (Guyer and Matthews's translation). 
Let us go back to the palace-one of Kant's examples-Rancière alludes to above:

"If someone asks me whether I find the palace that I see before me beautiful, I may well say that I don't like that sort of thing, which is merely to be gaped at ...; in true Rousseauesque style I might even vilify the vanity of the great who waste the sweat of the people on such superfluous things; finally I could even easily convince myself that if I were to find myself on an uninhabited island, without any hope of ever coming upon human beings again, and could conjure up such a magnificent structure through my mere wish, I would not even take the trouble of doing so if I already had a hut that was comfortable enough for me" $(C J, \S 2)$.

Kant is not suggesting that we should not care about these things. He is trying to establish one of the defining moments of aesthetic judgment; namely, that "the satisfaction that determines the judgment of taste is without any interest" $(C J, \S 2)$. Judgments of taste are distinguished by their disinterestedness. I may know all kinds of things about the palace, or I may not even care if the palace is there or not-none of hese determines my aesthetic judgment of the palace; my judgment must be disinterested. "The aesthetic gaze which sees the form of the palace is without relation with its functional perfection, and with its inscription in an order of society. It acts as if the gaze could be detached from the double rapport of the palace with the knowledge invested in its fabrication, and the knowledge of the social order which provides it with its context" (Rancière, 2006, pages 5-6). But where is the political element here?

\section{The cook and the critic}

In an essay entitled "The Skeptic", David Hume wrote:

"There is something approaching to principles in mental taste; and critics can reason and dispute more plausibly than cooks or perfumers. We may observe, however, that this uniformity among human kind hinders not, but that there is a considerable diversity in the sentiments of beauty and worth, and that education, custom, prejudice, caprice, and humour, frequently vary our taste of this kind" (2008, page 98).

Kant's response was the following:

"Thus although critics, as Hume says, can reason more plausibly than cooks, they still suffer the same fate as them. They cannot expect a determining ground for their judgement from proofs, but only from the reflection of the subject on his own state (of pleasure or displeasure), rejecting all precepts and rules" (CJ, §34, emphasis added).

There, then, we have it: anyone, be it a cook or a critic, a factory owner or a floorlayer, has the capacity for aesthetic judgment, for such judgments are not determined by concepts, rules, knowledge, desire, or interest. Kant thus refuses to submit the capacity for judgment under rules or the qualities of the person making it. The radical implication is that anyone has this capacity; one does not need to know the rules or have certain qualifications. In this sense, Kant's aesthetic implies a radically egalitarian politics as it not only declines to attribute rules or standards to aesthetic judgmentthereby removing possible sources of privilege and authority-but also implies the disruption of any imposed or consolidated subject positions. Neither the cook nor the critic are differentiated by their skills, authority, or legitimacy in making judgments of taste. There is here an aesthetic suspension: of knowledge, interest, desire, and established distributions of roles and aptitudes-indeed of any ground for privilege and hierarchy. This is the second Kantian legacy in Rancière's politics.

There is a moment of interruption in aesthetic judgment when the subject's interests, cognitive determinations, desires, and ambitions are suspended. For Hughes (2010), this suspension of our dominant inclinations suggests a politics because it implies an alternative way of relating to the world. Panagia draws the political implications of this by arguing that Kant's third Critique provides a theory of "decentred 
subject" and a "political critique of privilege", and refers to this as his "radical democratic project":

"For Kant, anyone can experience beauty precisely because no one can determine its conditions of existence. This is the egalitarian promise of Kantian aesthetics: both the cook and the critic are afforded the occasion for aesthetic experience and neither the cook nor the critic has the privilege of safeguarding the conditions for that experience. Taste is available, for Kant, regardless of privilege" (Panagia, 2009: page 31).

But what kind of equality can aesthetics promise? In Rancière's account, aesthetics was bound up, from its birth in the 18th century, with two competing forms of equality. The first opened up the field of art by erasing the line that separated art from non-art, art objects from everyday ones. It was the "kind of equality that went along with the beheading of the King of France and the sovereignty of the people" (2009a, page 37) as it involved a collapse of established hierarchies.

The second form of equality had to do with aesthetic experience. In his third Critique, Kant 'deprivileged' aesthetic experience by freeing it from knowledge and desire, which implied a nonhierarchical relation between the intellectual and sensory faculties. For Kant, we have different cognitive faculties that work together. The understanding provides the concepts. The imagination 'represents', so to speak, the senses; its role is to hold together under a form that which is received by our senses, which then is subsumed under concepts provided by the understanding. Therefore, there is, ordinarily, a hierarchical relation between the understanding and the imagination, where the latter operates under the rules provided by the former. What this means is that "in its ordinary employment, the imagination is not free at all. It operates under the strict rules of the understanding" (Gasché, 2003, page 149).

If this were always the case, aesthetic judgment would not be possible as its very condition is "the apprehension by the imagination of a manifold of intuition in the absence of any determinate concept" (Gasché, 2003, page 73). So, in aesthetic judgments upon the beautiful or the sublime, ${ }^{(15)}$ the imagination and the understanding enter into a different-nonhierarchical-relation. They are now in 'free play', as Kant calls it $(C J, \S 9)$, where no rule or concept governs. This absence of hierarchy and conceptual determination signals a freedom. In aesthetic judgments, therefore, "a certain freedom with respect to the sensible has been gained" (Gasché, 2003, page 164). There is a moment of freedom in the way I relate to the world, where I can judge an object or event in its particularity, in its-and my-freedom.

The political implications of this dehierarchisation were articulated by Schiller (2004/1795), who followed Kant in defining an 'aesthetic state' as 'a sphere of sensory equality where the supremacy of active understanding over passive sensibility was no longer valid" (Rancière, 2009a, page 37). This was political because the "power of the high classes was supposed to be the power of activity over passivity, of understanding over sensation, of the educated senses over the raw senses" (page 37). As Schiller wrote in his twenty-seventh letter:

"All other forms of communication divide society, because they relate exclusively either to the private sensibility or to the private skilfulness of its individual members, that is, to what distinguishes between one man and another; only the communication of the Beautiful unites society, because it relates to what is common to them all ... Everything in the aesthetic State, even the subservient tool, is a free citizen having equal rights with the noblest; and the intellect, which forcibly moulds the passive multitude to its designs, must here ask for its assent. Here, then, in the realm of aesthetic appearance, is fulfilled the ideal of equality" (pages 138-140). 
What Schiller proposes is not an abstract form of freedom and equality granted by the law, but a sensible experience that has its source in the capacity, shared by all, to judge aesthetically. This means that anyone - Castella, Gauny, the cook, or the criticcan make aesthetic judgments regardless of their individual skills, dispositions, and education; we are all equal in this capacity. Aesthetic judgment is egalitarian for Schiller since it relates members of society through their common capacity rather than dissociating them by providing grounds for privilege.

Aesthetic experience is "subject neither to the law of understanding, which requires conceptual determination, nor to the law of sensation, which demands an object of desire. Aesthetic experience suspends both laws at the same time. It therefore suspends the power relations which usually structure the experience of the knowing, acting and desiring subject" (Rancière, 2009c, page 97). Therefore, it not only "implies a certain disconnection from the habitual conditions of sensible experience" (Rancière, 2006, page 1), but also a dissensus, understood here as "the rupture of a certain agreement between thought and the sensible" that follows from the dehierarchisation of faculties (Rancière, 2009c, page 98). And this is the third Kantian legacy in Rancière's politics:

"The essence of politics is ... dissensus. But dissensus is not the opposition of interests or opinions. It is the production, within a determined, sensible world, of a given that is heterogeneous to it. This production defines, in a specific sense, an aesthetic of politics that has nothing to do with the aesthetization of forms of power or the manifestations of collectivity. Politics is aesthetic in that it makes visible what had been excluded from a perceptual field, and in that it makes audible what used to be inaudible. It inscribes one perceptual world within another" (Rancière, 2004b, page 226).

Politics, then, implies a disruption of established ways of seeing, being, and sense making - a reorganisation of the partition of the sensible. Let us now consider the aesthetic features of this disruption.

\section{Politics is sublime}

As we have seen, Rancière establishes a relation between Kant's 'two aesthetics'; that is, between forms of perceiving the world - the forms in and through which we perceive worldly phenomena-and modes of relating to the world, to what is presented to our senses, which implies modes of being in the world. The disruption of established forms of perceiving the world and relating to it implies dissensus, the essence of politics. "A dissensus", Rancière writes, "is not a conflict of interests, opinions, or values; it is a division put in the 'common sense': a dispute about what is given, about the frame within which we see something as given .... This is what I call a dissensus; putting two worlds in one and the same world. A political subject, as I understand it, is a capacity for staging such scenes of dissensus" (Rancière, 2004c, page 304, emphasis added). 'Common sense' is qualified because it is not used to refer to a shared capacity that renders aesthetic judgments universally communicable, allowing one "to get into community with others" (Arendt, following Kant), but to what is commonly made available to the senses and made to make sense- 'the frame', as it were, that conditions our forms of perceiving the world and modes of relating to it. The disruption of this 'frame', the alteration of established ways of knowing the world and worldly involvement, is the sublime element in Rancière's politics.

Panagia (2006, page 16) has argued that "Rancière's image of political thought is indebted to a Burkean account of the sublime". What drives his interpretation is Burke's emphasis on 'astonishment', a feeling produced in those moments when we are faced with an almost unrepresentable element that we are unable to take it in. The sublime 
comes as an interruption, filling the mind with astonishment and terror, and throws us back to "an antisocial state of radical individuality" (2006, page 86). For Burke, Panagia goes on to argue, this antisocial state brought about by the sublime experience was a threat for it instilled division. Rancière's politics, however, is not afraid of division; it is, indeed divisive in nature. Based on this element of division and the implications of unrepresentability, Panagia concludes that the Burkean sublime and Rancière's politics share the same aesthetic features.

In my view, however, Rancière's politics suggests the aesthetic features associated with the Kantian sublime. In Kant, too, we are overwhelmed by the power and magnitude of the sublime; the imagination is overcome as it cannot take in and give form to what is presented to our senses. This leads to a rupture in the hierarchical workings of the understanding and the imagination, which is a general feature of aesthetic experience for Kant. In the sublime, however, this rupture is a call to reason; it "takes us from the domain of aesthetics to that of morality" (Rancière, 2009c, page 89). This, however, is not the path I want to pursue. "Even though the sublime remains within aesthetics ... it gestures towards something else, namely, practical reason and morality. Nevertheless, privileging the sublime on these grounds would do violence to the Kantian conceptuality and uproot the sublime from the aesthetics to which it belongs" (Gasché, 2003, page 154). Therefore, while acknowledging the moral implications of the sublime for Kant, I wish to focus on its aesthetic features, which, I believe, Rancière's politics also suggests.

For Rancière, the political pertinence of aesthetic experience comes from the dissensus it occasions - a disagreement between the understanding and the imagination, between thought and the sensible. This makes "aesthetic experience to be politically significant - that is, to be more than a Kantian 'common sense' promising to bridge the gap between the refinement of the elite and the simplicity of the lower class" (2004d, page 12). Rancière is alluding to $\S 29$ of the third Critique here, where Kant tries to establish the grounds for the subjective necessity of the judgments of the sublime, so that we have a ground for the uncoerced assent of others with our judgment. Kant presumes that we can claim necessity for such judgments, and this is why the sublime is part of his transcendental philosophy. In principle, therefore, all humans share the a priori conditions for making judgments of the sublime, as they do for judgments of the beautiful. What is peculiar about the sublime is that these universally shared conditions need to be mediated-or, better yet, cultivated-by 'culture':

"In fact, without the development of moral ideas, that which we, prepared by culture, call sublime will appear merely repellent to the unrefined person. He will see in the proofs of the dominion of nature given by its destructiveness and in the enormous measure of its power, against which his own vanishes away to nothing, only the distress, danger, and need that would surround the person who was banished thereto. Thus the good and otherwise sensible Savoyard peasant... had no hesitation in calling all devotees of the icy mountains fools" $(C J, \S 29)$.

Despite this requirement of culture, however, Kant is careful to note that the judgment of the sublime "has its foundations in human nature" and this is the ground for necessity. Culture is required in judgments of sublime, but such judgments are not 'generated' by it $(C J, \S 29)$. Therefore, judgments of the sublime imply subjective necessity, but their claim on the assent of others requires this mediation by culture. Shapiro (2006) argues that Kant turns to such an idea of culture because he realises that the subjective necessity he attributed to judgments of taste and the whole idea of sensus communis is imperilled by the sublime. The encounter with the sublime challenges the idea of a naturally given and universally shared common sense, because it disrupts what he sought to establish: a coherent and universal locus from which the world of phenomena is synthesised. In this sense, the political implications of the third Critique lies in 
"Kant's discovery of the fragility of his synthesis-his reluctant recognition that there is no single place from which to partition the sensible world.... His inability to establish the subjective necessity he sought, when he evoked the encounter with the sublime, opens up the possibility of a plurality of loci of enunciation and thereby challenges the institutionalised perspectives that dominate those reigning political discourses that depend for their cogency on naturalising or rendering necessary contingent modes of facticity" (Shapiro, 2006, page 669).

This implies, in the language I have been using, multiple ways of knowing the world and relating to it. Shapiro's interpretation is informed by Deleuze's account of the Kantian synthesis and its fragility before the sublime (Deleuze, Kant Lecture, 28 March 1978). The synthesis consists in three operations: apprehension, reproduction, and recognition. We start with apprehension as we are given a multiplicity of things, which are themselves multiplicities of parts, which we successively apprehend. Through this process, we 'take in' the parts of a given phenomenon. Since the parts are successively apprehended, it will be necessary to bring them together somehow, as if bringing together the pieces of a jigsaw puzzle. The apprehension of the parts is therefore followed by the reproduction of the parts by the imagination. We now have a form of space and time, but something else is missing - something that would allow me to say of this form 'it's this'. I have synthesised the manifold, 'represented' it, but not yet related it to an object. A third operation, recognition, completes the process. This is the task of the understanding, which provides the concepts so that I can say: this is a dolphin, this is a flower. The spatiotemporal form is referred to a conceptual form, and the synthesis is now complete. Without the synthesis, it would be pure multiplicity. The synthesis allows us to make sense of the world of phenomena. But there are moments when the 'whole structure of perception is in the process of exploding'. This is the encounter with the sublime:

"I can no longer apprehend parts, I can no longer reproduce parts, and finally I can no longer recognize something, and in effect the sublime, as Kant says, is the formless and the deformed. It is the infinite as encompassing all of space, or the infinite as overturning all of space; if my synthesis of perception is suppressed, this is because my aesthetic comprehension is itself compromised (Deleuze, Kant Lecture, 28 March 1978, emphasis added).

Imagination is faced with its limits and it can no longer master the form of the object presented to our senses. Aesthetic comprehension, however, is not just a part of the synthesis described above; it is 'the basis that the synthesis rests on', not its ground, but its very foundation. What Kant discovers in the third Critique is the fragility of this foundation since "the sublime threatens at each instant to overwhelm the imagination's act of synthesis" (Deleuze, Kant Lecture, 4 April 1978).

We have already seen that, ordinarily, there is a hierarchical relation between the imagination and the understanding, where the former operates under the rules of the latter to synthesise the multiplicity of sensory data. The Kantian synthesis - the Kantian way of knowing the world, making sense of it - has to abide by certain temporal and spatial rules: successive apprehension of sensory data and subsumption under concepts. It is, in a sense, a 'police', to use Rancière's term, a form and mode of governing the distribution of the sensible, working in an orderly, hierarchical way. It is a form and mode of spatialisation, where spatialisation refers both to giving a spatial form (representation) and to placement (recognition); that is, subsumption under a concept. But the sublime "defies all subsumption under the powers of cognition" as it involves "a representation that is infinitely rebellious against all cognition" (Gasché, 2003, page 125). The sublime encounter disrupts this spatial order, thus disrupting ordinary forms and modes of relating to the world. The sublime is what 
disrupts the ordinary functioning of this police order by introducing an element that overwhelms it.

Evoking the image of the sublime in relation to Rancière's politics raises a question given his criticism of Lyotard. However, Rancière is not critical of the sublime as such, but of the use Lyotard makes of it. In his view (2004d; 2009c), Lyotard is guilty of overturning the aesthetics of the sublime into ethics, of transforming sublime unrepresentability into an ethical imperative of absolute respect for otherness. ${ }^{(16)}$ By associating Rancière's politics with the aesthetic features of the sublime, I do not mean to imply an ethics informed by the radical unrepresentability of the other. Rather, I emphasise an understanding of politics informed by the unrepresentability of political subjects qua political subjects before they disrupt the police order. A political subject, for Rancière, is anyone and noone in particular. I am not, therefore, endorsing a notion of politics animated by a categorical resistance to all possible representation, but by a form of unrepresentability in so far as it implies that there are no given, 'natural' political subjects. Political subjects come to the police order as an excess, as "subjects whose count is always supernumerary" (Rancière, 1999, page 58). This supernumerarity ensures for Rancière that the police does not become total closure and that politics remains a permanent possibility. Therefore, what I try to capture with the image of the sublime is the nonexhaustiveness of political subjects in established orders of representation, rather than an unconditional valorisation of ultimate unrepresentability.

But there is still the question of disruption that the image of the sublime evokes. Although I use the sublime to imply a disruption of 'inherited', 'habitual', 'common sense' ways of perceiving and making sense of the world, this is not meant to advocate an understanding of politics that privileges disruption for its own sake. We have seen the limits and perils of such an understanding with Cascardi above-a sort of touchand-go politics that could end up in a wide spectrum ranging from emancipation to totalitarianism. Rancière's conceptualisation eschews this problem by emphasising 'wrong' and posing equality as the universal of politics.

Politics, Rancière argues, "is a function of the fact that a wrong exists, an injustice that needs to be addressed" (1995a, page 97). This wrong, however, is not a juridical wrong (which could be resolved by the institutions of the police) or an infinite debt (as Lyotard's ethics seems to imply), but a form of injustice that is produced when governing orders 'wrong' equality. ${ }^{(17)}$ Such instances when equality is 'wronged' call for the staging of dissensus for the handling of a wrong and the verification of equality, which, we have seen, Rancière takes as axiomatic. "[T]he only universal in politics", he writes, "is equality" (1995b, page 65). ${ }^{(18)}$

Arendt and Rancière offer different ways of mobilising 'aesthetics' in understanding politics. Arendt focuses on judgment as a world-making practice because her political aesthetic is based on the creation of common worlds through a plurality of encounters. Kant's notion of aesthetic judgment liberates her from the rigidity of truth claims,

(16) Hutchings (1996, page 188) seems to concur: "Lyotard rewrites the categorical imperative as an absolute respect for otherness."

(17) Rancière plays on the word 'wrong' (le tort), which comes from the verb 'tordre', to twist.

(18) "I do not reduce politics to a mere agonistic schema where the 'content' is irrelevant ... . Politics, I argue, has its own universal, its own measure that is equality. The measure never applies directly. It does so only through the enactment of a wrong. However, not every wrong is necessarily political. It has been argued against my thesis that there are also anti-democratic forms of protest among the oppressed, shaped by religious fanaticism or ethnic identitarianism and intolerance. Ernesto Laclau put this as the blind spot of my conceptualisation of dissensus. But it is clear that in my view a wrong is political when it enacts the basis of political action, which is the mere contingency of equality, which is evidently not the case of 'popular' movements asking for the purity of the blood, the power of religion and so on" (Rancière, 2003, page 4). 
rules, and standards. It also allows her to conceive the creation of common worlds through uncoerced assent with an appeal to common sense, which she seems to take as a given. Rancière's politics involves disruption of 'common sense', understood as habitual or routinised ways of perceiving and making sense of the world. He starts with a premise - axiomatic equality - but locates moments of its negation or verification in historical contexts. The distribution of the sensible is an empirical problem for Rancière, and it is in these contingent spatialisations that his axiomatic equality is 'wronged' by police orders or verified by political subjects staging dissensus, altering forms and modes of relating to the world.

Despite their differences, however, both Arendt and Rancière suggest a political relation to the world that is not one of knowing, but one of aesthetics. Such an orientation makes possible an understanding of politics as the disruption of normalised coordinates of sensory experience and established practices of sensemaking, allowing Castella, Gauny, the cook, and the critic to undermine grounds of privilege by affirming their capacity, verifying the equality of anyone with anyone.

Acknowledgements. I am grateful to Emily Brady, Claire Hancock, and two anonymous referees for their constructive comments.

\section{References}

Allison E H, 2001 Kant's Theory of Taste: A Reading of the Critique of Aesthetic Judgment (Cambridge University Press, Cambridge)

Arendt H, 1978 The Life of the Mind. Volume I: Thinking (Harcourt Brace Jovanovich, New York) Arendt H, 1992 Lectures on Kant's Political Philosophy Ed. R Beiner (University of Chicago Press, Chicago, IL)

Arendt H, 1998 [1958] The Human Condition 2nd edition (University of Chicago Press, Chicago, IL)

Arendt H, 2005 The Promise of Politics Ed. J Kohn (Schocken Books, New York)

Arendt H, 2006 Between Past and Future Ed. J Kohn (Penguin Books, New York)

Beiner R, 1992, "Interpretive essay: Hannah Arendt on judging", in Lectures on Kant's Political Philosophy H Arendt, Ed. R Beiner (University of Chicago Press, Chicago, IL) pp 87-156

Beiner R, Nedelsky J, 2001, "Introduction", in Judgment, Imagination, and Politics: Themes from Kant and Arendt Eds R Beiner, J Nedelsky (Rowman and Littlefield, Lanham, MD) pp vii - xxvi

Burke E, 1998 [1757] A Philosophical Enquiry into the Origin of our Ideas of the Sublime and Beautiful and Other Pre-revolutionary Writings Ed. D Womersley (Penguin Books, London)

Cascardi A, 1997, "Communication and transformation: aesthetics and politics in Kant and Arendt", in Hannah Arendt and the Meaning of Politics Eds C Calhoun, J McGowan (University of Minnesota Press, Minneapolis, MN) pp $99-131$

Curtis K, 1997, "Aesthetic foundations of democratic politics in the work of Hannah Arendt", in Hannah Arendt and the Meaning of Politics Eds C Calhoun, J McGowan (University of Minnesota Press, Minneapolis, MN) pp $27-52$

Deleuze G, 1978, "Kant lectures of 28/03/1978 and 04/04/1978”, translated by M McMahon, available at http://www.webdeleuze.com/php/sommaire.html

Dikeç M, 2005, "Space, politics, and the political" Environment and Planning D: Society and Space $23171-188$

Ferguson K, 2007 The Politics of Judgement: Aesthetics, Identity, and Political Theory (Lexington Books, Lanham, MD)

Ferrara A, 2008 The Force of the Example: Explorations in the Paradigm of Judgment (Columbia University Press, New York)

Fraser N, 1997, "Communication, transformation, and consciousness-raising", in Hannah Arendt and the Meaning of Politics Eds C Calhoun, J McGowan (University of Minnesota Press, Minneapolis, MN) pp $166-175$

Gasché R, 2003 The Idea of Form: Rethinking Kant's Aesthetics (Stanford University Press, Stanford, CA)

Hughes F, 2010 Kant's Critique of Aesthetic Judgement (Continuum, London)

Hume D, 2008 Selected Essays Eds S Copley, A Edgar (Oxford University Press, Oxford)

Hutchings K, 1996 Kant, Critique and Politics (Routledge, London)

Jay M, 1992, “'The aesthetic ideology' as ideology: or, what does it mean to aestheticize politics?" Cultural Critique 21 (Spring) $41-61$ 
Jay M, 1997, "Reflective judgments by a spectator on a conference that is now history", in Hannah Arendt and the Meaning of Politics Eds C Calhoun, J McGowan (University of Minnesota Press, Minneapolis, MN) pp $338-350$

Kant I, 1998 [1781] Critique of Pure Reason translated and edited by P Guyer, A W Wood (Cambridge University Press, Cambridge)

Kant I, 2000 [1790] Critique of the Power of Judgment translated by P Guyer, E Matthews (Cambridge University Press, Cambridge)

Kateb G, 2001, "The judgment of Arendt", in Judgment, Imagination, and Politics: Themes from Kant and Arendt Eds R Beiner, J Nedelsky (Rowman and Littlefield, Lanham, MD) pp 121 - 138

McClure K, 1997, "The odor of judgment: exemplarity, propriety, and politics in the company of Hannah Arendt", in Hannah Arendt and the Meaning of Politics Eds C Calhoun, J McGowan (University of Minnesota Press, Minneapolis, MN) pp 53-84

Panagia D, 2006 The Poetics of Political Thinking (Duke University Press, Durham, NC)

Panagia D, 2009 The Political Life of Sensation (Duke University Press, Durham, NC)

Passerin d'Entrèves M, 2000, "Arendt's theory of judgment", in The Cambridge Companion to Hannah Arendt Ed. D R Villa (Cambridge University Press, Cambridge) pp 245-260

Rancière J, 1989 The Nights of Labor: The Workers' Dream in Nineteenth-century France translated by J Drury (Temple University Press, Philadelphia, PA)

Rancière J, 1991 The Ignorant Schoolmaster: Five Lessons in Intellectual Emancipation translated by K Ross (Stanford University Press, Stanford, CA)

Rancière J, 1995a On the Shores of Politics translated by L Heron (Verso, London)

Rancière J, 1995b "Politics, identification, and subjectivization", in The Identity in Question Ed. J Rajchman (Routledge, London) pp $63-70$

Rancière J, 1999 Disagreement: Politics and Philosophy translated by J Rose (University of Minnesota Press, Minneapolis, MN)

Rancière J, 2000, "Jacques Rancière: literature, politics, aesthetics: approaches to democratic disagreement", interviewed by S Guénoun, J H Kavanagh SubStance 29(2) 3-24

Rancière J, 2003, "The thinking of dissensus: politics and aesthetics", paper presented at the conference 'Fidelity to the Disagreement: Jacques Rancière and the Political', Goldsmiths College, London, 16 - 17 September, copy available from the author

Rancière J, 2004a The Politics of Aesthetics translated by G Rockhill (Continuum, London)

Rancière J, 2004b The Philosopher and His Poor translated by J Drury, C Oster, A Parker (Duke University Press, Durham, NC)

Rancière J, 2004c "Who is the subject of the rights of man?" The South Atlantic Quarterly 103 $297-310$

Rancière J, 2004d "The sublime from Lyotard to Schiller: two readings of Kant and their political significance" Radical Philosophy 126(July/August) 8-15

Rancière J, 2005, "From politics to aesthetics?" Paragraph 28(1) 13 - 25

Rancière J, 2006, "Thinking between disciplines: an aesthetics of knowledge" Parrhesia number 1, $1-12$

Rancière J, 2009a, "Contemporary art and the politics of aesthetics", in Communities of Sense: Rethinking Aesthetics and Politics Eds B Hinderliter, J Mansoor, S McCormick (Duke University Press, Durham, NC) pp $31-50$

Rancière J, 2009b, "Politique de l'indétermination esthétique", in Jacques Rancière et la politique de l'esthétique Eds J Game, A W Lasowski (Éditions des archives contemporaines, Paris) pp $157-175$

Rancière J, 2009c Aesthetics and its Discontents translated by S Corcoran (Polity Press, Cambridge)

Schiller F, 2004 [1795] On the Aesthetic Education of Man translated by R Snell (Dover Publications, New York)

Shapiro M, 2006, "The sublime today: re-partitioning the global sensible" Millennium: Journal of International Studies $34657-681$

Villa R D, 2000, "Introduction. The development of Arendt's political thought", in The Cambridge Companion to Hannah Arendt Ed. D R Villa (Cambridge University Press, Cambridge) pp 1-21

Villa R D, 2001, "Hannah Arendt: modernity, alienation, and critique", in Judgment, Imagination, and Politics: Themes from Kant and Arendt Eds R Beiner, J Nedelsky (Rowman and Littlefield, Lanham, MD) pp $287-310$

\section{Filmography}

Jaoui A, (Dir), 2000 Le Goût des Autres (Pathé) 
Conditions of use. This article may be downloaded from the E\&P website for personal research by members of subscribing organisations. This PDF may not be placed on any website (or other online distribution system) without permission of the publisher. 